\title{
PENGARUH PENDIDIKAN KESEHATAN DENGAN METODE CERAMAH PLUS DISKUSI DAN TUGAS (CPDT) TERHADAP PENGETAHUAN DAN SIKAP REMAJA PUTRI TENTANG PENCEGAHAN KEPUTIHAN DI SMPN 29 SURABAYA
}

\author{
Erlita Kusuma R
}

\begin{abstract}
Flour albus incidents increase every year. Flour albus is a normal condition but it will be dangerous if flour albums becomes ill smelling, color of fluid, itching, and in a large amount. The low level of the female teenagers knowledge about flour albus prevention will cause negative attitudes. Lecture plus discussion and assignment (CPDT) methods used to accompany respondents on health education. This method was expected to change the knowledge and attitude of persons in order to increase his health quality.

The research used pre experimental with one group pre post test design. Population subject of this research is the female teenagers. Questioner filled before and after the researcher give lecture plus discussion and assignment (CPDT) method to 14 respondents who fulfil the inclusion criteria. Independent variable is health education with lecture plus discussion and assignment (CPDT) method. Dependent variable is female teenagers knowledge and attitude. Data was collected and then analyzed by using Wilcoxon Signed Rank Test with significant value $\mathrm{p} \leq 0.05$.

'This results showed that there was effect of lecture plus discussion and assignment (CPDT) method on the female teenagers knowledge and attitude about flour albus prevention. Based on that results we can concluded that the lecture plus discussion and assignment (CPDT) method can be able to increase knowledge $(\mathrm{p}=0,001)$ and attitude $(\mathrm{p}=0,002)$. Adequate and effective information through lecture plus discussion and assignment (CPDT) method can increase knowledge. It will influence the positive attitude and action at daily activity.

Hopefully, this research impact on decresing number of flour albus incidens in female teenagers through an effective health education methods.
\end{abstract}

Keywords: CPDT methods, knowledge, attitude, flour albus

\section{PENDAHULUAN}

Keputihan adalah cairan yang keluar dari vagina secara berlebihan dan disertai dengan keluhan yang tergantung dari tingkat pengetahuan. Sebanyak $75 \%$ remaja putri yang mengalami keputihan belum mengetahui tentang keputihan dan menganggap keputihan yang dialami merupakan hal yang wajar. Pada usia 11 sampai 13 tahun, remaja mulai mengalami perubahan fisik yang sangat cepat seperti kematangan organ dan fungsi reproduksi. Keputihan yang dialami remaja putri terjadi saat pertama kali mengalami menstruasi dan akan terjadi pada siklus menstruasi berikutnya. Keputihan merupakan hal normal jika tidak gatal, tidak berbau, dan berwarna jernih namun keputihan dapat menjadi berbau, berwarna kuning kehijau-hijauan, gatal dan dalam jumlah banyak yang disebut keputihan patologis (Sugi, 2004; Bobak, 2005; Suhandi, 2006). Keputihan patologis merupakan salah satu tanda terdapat gejala penyakit pada organ reproduksi seperti kanker serviks yang merupakan penyakit yang membahayakan bagi wanita setelah kanker payudara. Salah satu penyebab penyakit pada organ reproduksi akibat wanita atau remaja putri belum mengerti cara menjaga kesehatan organ reproduksi. Penelitian Wijayanti (2004) 
dari 287 siswi didapatkan 63,3\% perilaku siswi SMAN 1 Cepiring Kendal masih rendah dalam mencegah terjadinya keputihan. Survei yang dilakukan Youth Center Pilar PKBI Jawa Tengah (2004) di Semarang mengungkapkan sebanyak $43,22 \%$ pengetahuan remaja tentang cara menjaga organ reproduksi dan fungsi organ reproduksi masih kurang. Berdasarkan survei yang dilakukan oleh peneliti pada tanggal 29 April 2008 di SMPN 29 Surabaya sebanyak 129 siswi kelas VIII didapatkan $62,41 \%$ mengalami keputihan dan sebanyak $52,06 \%$ perilaku siswi dalam mencegah terjadi keputihan masih kurang seperti cara membersihkan diri setelah BAK, memakai celana jeans setiap hari, tidak mengganti celana dalam minimal dua kali dalam sehari. Perilaku yang sehat didasari pada pemahaman yang berasal dari pendidikan kesehatan (Ilyana, 2000). Metode pembelajaran yang diberikan berpengaruh pada penerimaan dan pemahaman remaja putri tentang informasi yang disampaikan. Strategi pembelajaran yang baik untuk meningkatkan pengetahuan dan sikap positif adalah dengan mengikutsertakan peseta didik untuk berpartisipasi (Sudjana, 2005). Salah satu metode pembelajaran partisipatif adalah metode ceramah plus diskusi dan tugas (CPDT). Belum diketahui pengaruh pendidikan kesehatan dengan metode ceramah plus diskusi dan tugas (CPDT) terhadap pengetahuan dan sikap remaja putri tentang pencegahan keputihan.

Faktor keingintahuan remaja yang tinggi membuat remaja berusaha untuk mendapatkan informasi dari luar seperti dari media massa atau teman sebaya yang belum tentu benar sehingga perilaku remaja putri dalam mencegah keputihan masih belum dapat dipertanggungjawabkan. Pemilihan metode dalam menyajikan informasi kurang tepat sasaran juga mempengaruhi keberhasilan dalam pembelajaran dan peningkatan pengetahuan dan sikap peserta didik.
Pendidikan kesehatan merupakan kegiatan pendidikan dengan menyebarkan informasi, menanamkan keyakinan sehingga masyarakat tidak hanya sadar, tahu, dan mengerti tetapi juga mau dan bisa melakukan anjuran yang ada hubungannya dengan kesehatan (Azwar, 2003). Penggunaan metode dalam penyampaian pendidikan kesehatan mempengaruhi penerimaan dan pemahaman responden (Martadisoebrata, 2005). Metode ceramah plus diskusi dan tugas (CPDT) adalah salah satu metode yang mengikutsertakan partisipasi remaja putri dalam proses pembelajaran sehingga maksud pendidikan kesehatan terjadi proses perubahan tingkat pengetahuan dan sikap positif dapat terjadi.

\section{METODOLOGI PENELITIAN}

Penelitian ini menggunakan metode penelitian Pre Experimental Design dengan rancangan penelitian one group pre-post test design. Tujuan penelitian ini adalah untuk mengetahui pengaruh pendidikan kesehatan metode ceramah plus diskusi dan tugas (CPDT) tentang keputihan terhadap pengetahuan dan sikap remaja putri tentang pencegahan keputihan di SMPN 29 Surabaya. Populasi dalam penelitian ini populasi target dalam penelitian ini sebanyak 129 siswi kelas VIII, sedangkan populasi terjangkau penelitian ini sebanyak 81 siswi kelas VIII yang mengalami keputihan. Setelah diseleksi sesuai dengan kriteria inklusi didapatkan sampel sebanyak 14 siswi. Pengambilan sampel dilakukan dengan cara Non Probability Sampling dengan teknik Purposive Sampling. Pada penelitian ini, peneliti menggunakan instrumen kuesioner untuk mengukur pengetahuan dan sikap tentang pencegahan keputihan. 
HASILPENELITIAN

1. Data Umum Kelompok Eksperimen

a. Karakteristik Berdasarkan Usia

Tabel 1

Distribusi responden berdasarkan usia di SMPN 29 Surabaya

\begin{tabular}{|l|l|l|}
\hline No & Usia & Prosentase \\
\hline 1 & 13 tahun & $57 \%$ \\
\hline 2 & 14 tahun & $43 \%$ \\
\hline
\end{tabular}

Pada tabel 1 menunjukkan karakteristik responden berdasarkan usia menunjukkan dari 14 responden sebanyak (57\%) responden berusia 13 tahun sisanya sebanyak (43\%) berusia 14 tahun.

\section{.b. Karakteristik}

Responden

Berdasarkan Urutan Anak Dalam Keluarga

Tabel 2

Distribusi karakteristik responden berdasarkan urutan anak dalam keluarga di SMPN 29 Surabaya.

\begin{tabular}{|l|l|l|}
\hline No & Urutan & Prosentase \\
\hline 1 & Anak ke-1 & $1,43 \%$ \\
\hline 2 & Anak ke-2 & $36 \%$ \\
\hline 3 & Anak ke-3 & $14 \%$ \\
\hline 4 & Lainnya & $1,7 \%$ \\
\hline & Jumlah & $100 \%$ \\
\hline
\end{tabular}

Tabel 2 menunjukkan karakteristik responden berdasarkan urutan anak dalam keluarga. Sebagian besar responden (43\%) merupakan anak pertama dalam keluarga.

\section{c. Karakteristik Responden Berdasarkan Pekerjaan Ayah}

\section{Tabel 3}

Distribusi responden berdasarkan pekerjaan ayah di SMPN 29 Surabaya

\begin{tabular}{|l|l|l|l|l|}
\hline $\begin{array}{l}\text { N } \\
\mathrm{o}\end{array}$ & $\begin{array}{l}\text { Pekerja } \\
\text { an ayah }\end{array}$ & $\begin{array}{l}\text { Prose } \\
\mathrm{n}\end{array}$ & $\begin{array}{l}\text { Pekerja } \\
\text { an ibu }\end{array}$ & $\begin{array}{l}\text { Prose } \\
\mathrm{n}\end{array}$ \\
\hline 1 & $\begin{array}{l}\text { PNS/ } \\
\text { honorer }\end{array}$ & $21 \%$ & $\begin{array}{l}\text { PNS/ } \\
\text { honorer }\end{array}$ & $43 \%$ \\
\hline 2 & $\begin{array}{l}\text { Wira- } \\
\text { swasta }\end{array}$ & $29 \%$ & $\begin{array}{l}\text { Wira- } \\
\text { swasta }\end{array}$ & $14 \%$ \\
\hline 3 & $\begin{array}{l}\text { Pegawai } \\
\text { swasta }\end{array}$ & $36 \%$ & $\begin{array}{l}\text { Pegawa } \\
\text { i swasta }\end{array}$ & $7 \%$ \\
\hline
\end{tabular}

\begin{tabular}{|l|l|l|l|l|}
\hline 4 & $\begin{array}{l}\text { Tidak } \\
\text { bekerja }\end{array}$ & $7 \%$ & $\begin{array}{l}\text { Tidak } \\
\text { bekerja }\end{array}$ & $36 \%$ \\
\hline 5 & Lainnya & $7 \%$ & $\begin{array}{l}\text { Lainny } \\
\text { a }\end{array}$ & $0 \%$ \\
\hline & Jumlah & $100 \%$ & Jumlah & $100 \%$ \\
\hline \multicolumn{5}{r|}{ Pada tabel 3 menunjukkan }
\end{tabular}

distribusi responden karakteristik pekerjaan ayah dan ibu. Menurut Depsos (2005) menyatakan tingkat ekonomi orang tua mempengaruhi gaya hidup remaja.

\section{d. Karakteristik Berdasarkan Tingkat Pendidikan Ayah dan Ibu.}

Tabel 4

Distribusi responden berdasarkan tingkat pendidikan ayah dan ibu di SMPN 29 Surabaya.

\begin{tabular}{|l|l|l|l|l|}
\hline No & $\begin{array}{l}\text { Pendidikan } \\
\text { ayah }\end{array}$ & Prosen & $\begin{array}{l}\text { Pendidikan } \\
\text { ibu }\end{array}$ & Prosen \\
\hline 1 & SD/MI & $0 \%$ & SD/MI & $0 \%$ \\
\hline 2 & SLTP & $0 \%$ & SLTP & $14 \%$ \\
\hline 3 & SMA & $71 \%$ & SMA & $43 \%$ \\
\hline 4 & PT & $29 \%$ & PT & $43 \%$ \\
\hline & Jumlah & $100 \%$ & Jumlah & $100 \%$ \\
\hline
\end{tabular}

Sebagian besar tingkat pendidikan ayah dan ibu dari responden berasal dari SMA dan perguruan tinggi. Menurut Notoadmodjo (2003) menyatakan semakin tinggi pendidikan seseorang maka semakin mudah dalam pemberian informasi. 
2. Data Khusus

\section{a. Data Khusus pada Kelompok Eksperimen \\ Tabel 7}

Distribusi responden berdasarkan pengetahuan sebelum dan sesudah diberikan pendidikan kesehatan dengan metode ceramah plus diskusi dan tugas di SMPN 29 Surabaya

\begin{tabular}{|l|l|l|l|l|}
\hline $\begin{array}{l}\text { N } \\
\text { o }\end{array}$ & $\begin{array}{l}\text { penget } \\
\text { ahuan } \\
\text { sebelu } \\
\text { m } \\
\text { CPDT }\end{array}$ & $\begin{array}{l}\text { Prose } \\
\mathrm{n}\end{array}$ & $\begin{array}{l}\text { Penge- } \\
\text { tahuan } \\
\text { setelah } \\
\text { CPDT }\end{array}$ & $\begin{array}{l}\text { Prose } \\
\mathrm{n}\end{array}$ \\
\hline 1 & Kurang & $29 \%$ & Kurang & $0 \%$ \\
\hline 2 & Cukup & $71 \%$ & Cukup & $0 \%$ \\
\hline 3 & Baik & $0 \%$ & Baik & $100 \%$ \\
\hline & Jumlah & $100 \%$ & Jumlah & $100 \%$ \\
\hline
\end{tabular}

Tabel 7 menunjukkan karakteristik responden berdasarkan pengetahuan remaja putri sebelum dan sesudah diberikan pendidikan kesehatan. Pengetahuan responden sebelum diberikan pendidikan kesehatan dengan metode ceramah plus diskusi dan tugas (CPDT) sebanyak 4 orang (29\%) memiliki pengetahuan kurang, sisanya sebanyak 10 orang $(71 \%)$ memiliki pengetahuan cukup. Pengetahuan responden setelah diberikan intervensi pendidikan kesehatan meningkat (100\%) yaitu seluruh responden memiliki pengetahuan yang baik.

\section{Tabel 8}

Distribusi sikap remaja putri tentang pencegahan keputihan sebelum dan sesudah diberikan pendidikan kesehatan dengan metode ceramah plus diskusi dan tugas (CPDT)

\begin{tabular}{|l|l|l|l|l|}
\hline No & $\begin{array}{l}\text { Sikap } \\
\text { sebelum } \\
\text { CPDT }\end{array}$ & Prosen & $\begin{array}{l}\text { Sikap } \\
\text { setelah } \\
\text { CPDT }\end{array}$ & Prosen \\
\hline 1 & Negatif & $50 \%$ & Negatif & $21 \%$ \\
\hline 2 & Positif & $50 \%$ & Positif & $71 \%$ \\
\hline & Jumlah & $100 \%$ & Jumlah & $100 \%$ \\
\hline
\end{tabular}

Tabel 8 menunjukkan karakteristik responden berdasarkan sikap responden sebelum dan sesudah diberikan intervensi pendidikan kesehatan. Sikap responden sebelum diberikan pendidikan kesehatan dengan metode ceramah plus diskusi dan tugas (CPDT) sebanyak 7 orang (50\%) memiliki sikap negatif dan sebanyak 7 orang (50\%) memiliki sikap positif. Setelah diberikan pendidikan kesehatan dengan metode ceramah plus diskusi dan tugas (CPDT), sikap positif responden meningkat sebesar $(79 \%)$ sisanya sebesar (21\%) masih memiliki sikap negatif.

\section{Hasil Uji Statistik}

Tabel 9

Pengaruh pendidikan kesehatan dengan metode ceramah plus diskusi dan tugas (CPDT) terhadap tingkat pengetahuan remaja putri.

\begin{tabular}{|l|l|l|}
\hline Pengetahuan & Sebelum & Sesudah \\
\hline Baik & 0 & 14 \\
\hline Cukup & 10 & 0 \\
\hline Kurang & 4 & 0 \\
\hline Total & 14 & 14 \\
\hline Mean & 57,57 & 96,21 \\
\hline SD & 11,83 & 3,64 \\
\hline $\begin{array}{l}\text { Uji Wicoxon } \\
\text { Signed Rank } \\
\text { Test }\end{array}$ & $\mathrm{p}=0,001$ \\
\hline
\end{tabular}

Tabel 10

Pengaruh pendidikan kesehatan dengan metode ceramah plus diskusi dan tugas (CPDT) terhadap sikap remaja putri.

\begin{tabular}{|l|l|l|}
\hline Sikap & Sebelum & Sesudah \\
\hline Negatif & 7 & 4 \\
\hline Positif & 7 & 10 \\
\hline Total & 14 & 14 \\
\hline Mean & 44,78 & 54,64 \\
\hline SD & 4,35 & 2,68 \\
\hline $\begin{array}{l}\text { Uji Wicoxon } \\
\text { Signed Rank } \\
\text { Test }\end{array}$ & $\mathrm{p}=0.002$ \\
\hline
\end{tabular}

\section{Pembahasan}

1. Pengaruh pendidikan kesehatan dengan metode ceramah plus diskusi dan tugas (CPDT) terhadap tingkat pengetahuan remaja putri di SMPN 29 Surabaya

Pada tabel 8 didapatkan perbedaan tingkat pengetahuan remaja putri di SMPN 29 Surabaya sebelum dan sesudah intervensi 
pendidikan kesehatan dengan metode ceramah plus diskusi dan tugas (CPDT). Sebelum pendidikan kesehatan diberikan, tingkat pengetahuan remaja putri sebagian besar dalam kategori cukup. Hal ini bisa disimpulkan bahwa remaja putri sudah mengetahui tentang definisi keputihan namun belum mengetahui dan memahami dengan jelas tentang bagaimana cara pencegahan keputihan dan dampak dari keputihan tersebut. Hal ini salah satunya disebabkan oleh informasi yang didapatkan remaja putri masih kurang. Penyebab informasi yang masih kurang disebabkan oleh : 1) faktor orang tua. Tingkat pendidikan orang tua responden khususnya pada ibu sebagian besar adalah lulusan dari perguruan tinggi. Sebagian besar pemikiran orang tua masih menganggap tabu untuk membicarakan tentang perkembangan dan fungsi organ reproduksi pada anak perempuan yang sudah beranjak dewasa. Sedangkan rasa ingin tahu yang tinggi pada remaja putri membuat mereka berupaya mencari informasi dari luar seperti media massa, teman sebaya maupun dari internet yang sebenarnya masih perlu mendapatkan bimbingan dan penjelasan tentang apa yang mereka ketahui karena tidak semua informasi yang didapatkan benar; 2) faktor urutan anak dalam keluarga. Sebagian besar responden merupakan anak pertama dalam keluarga. Menurut Erikson (1968) dalam Potter\&Perry (2005) menyatakan bahwa pada masa remaja, tahap perkembangan psikososial, remaja lebih dekat dengan teman sebaya atau orang lain. Jika mereka mengalami masalah kesehatan organ reproduksi, mereka cenderung untuk menceritakan atau bertanya kepada kakak perempuan atau orang lain yang sebaya daripada orang tua karena merasa malu atau canggung.

Menurut Keraf (2001) pengetahuan merupakan keseluruhan pemikiran, gagasan, ide, konsep dan pemahaman yang dimiliki oleh manusia. Menurut Azwar (2003) pengetahuan seseorang tentang suatu obyek mengandung 2 aspek yaitu aspek positif dan aspek negatif. Kedua aspek inilah akan menentukan sikap seseorang terhadap obyek tertentu, semakin banyak aspek positif dari suatu obyek diketahui menimbulkan sikap makin positif terhadap obyek tersebut. Tingkat pengetahuan remaja putri setelah diberikan pendidikan kesehatan didapatkan peningkatan yang signifikan. Peningkatan pengetahuan responden setelah pendidikan kesehatan dipengaruhi oleh : 1) metode penyampaian yang diberikan, dalam penelitian ini, peneliti menggunakan metode ceramah plus diskusi dan tugas (CPDT) dimana metode ini merupakan kombinasi dari beberapa metode pembelajaran yang lain, menurut Gulo W (2002) menyatakan bahwa ceramah hanya efektif selama 30 menit setelah itu diganti dengan metode diskusi kelompok dan tugas, dengan demikian interaksi dalam pendidikan kesehatan menjadi bervariasi dan tidak membosankan. Peran perawat disini sebagai pemberi informasi atau educator, sehingga sangat diperlukan suatu kemampuan untuk menganalisis metode pengajaran yang sesuai dengan kemampuan dan kebutuhan klien. Hal ini sesuai dengan teori Watson yang menyatakan bahwa perawatan manusia membutuhkan perawat yang memahami perilaku dan respons manusia terhadap masalah kesehatan yang aktual ataupun yang potensial, kebutuhan manusia dan bagaimana berespons terhadap orang lain dan memahami kekurangan dan kelebihan klien dan keluarganya, sekaligus pemahaman pada dirinya sendiri.

\section{Pengaruh pendidikan kesehatan dengan metode ceramah plus diskusi dan tugas (CPDT) terhadap sikap remaja putri di SMPN 29 Surabaya}

Tabel 9 didapatkan sikap sebelum pendidikan kesehatan dengan metode ceramah plus diskusi dan tugas (CPDT) menunjukkan sikap positif dan sikap negatif responden sama besarnya. Sikap 
negatif responden dikarenakan pengetahuan dan pemahaman tentang pencegahan dan dampak keputihan patologis yang masih kurang. Sikap positif yang ditunjukkan oleh responden sebelum pendidikan kesehatan dengan metode ceramah plus diskusi dan tugas (CPDT) dikarenakan oleh tingkat pengetahuan remaja serta dukungan keluarga yang sudah baik sehingga memotivasi remaja putri untuk bersikap positif ditunjang dengan kesadaran dan kemauan untuk menjaga kesehatan organ reproduksi.

Sikap merupakan suatu keteraturan tertentu dalam hal perasaan (afeksi), pemikiran (kognisi), dan predisposisi tindakan (konasi) terhadap suatu aspek dilingkungan sekitarnya. Pengetahuan yang baik akan menghasilkan sikap yang positif. Menurut Azwar (2003) komponen kognitif merupakan representasi dari apa yang dipercayakan seseorang mengenai nilai yang berlaku, nilai yang benar bagi objek sikap. Sikap seseorang dapat berubah dengan diperolehnya tambahan informasi tentang objek tersebut, melalui persuasi serta tekanan dari kelompok sosialnya (Sarwono, 1993). Faktor-faktor yang mempengaruhi pembentukan sikap adalah : 1) pengalaman pribadi. Apa yang telah dan sedang dialami seseorang ikut membentuk dan mempengaruhi penghayatan seseorang terhadap stimulus yang menjadi salah satu dasar terbentuknya sikap; 2) pengaruh orang lain. Orang lain merupakan salah satu komponen yang ikut mempengaruhi sikap. Pada umumnya individu cenderung memiliki sikap yang searah dengan sikap yang dianggap penting oleh orang lain; 3) pengaruh kebudayaan. Suatu kebudayaan turut mempengaruhi pemikiran seseorang untuk bersikap ; 4) media massa. Media massa mempunyai pengaruh besar dalam pembentukan kepercayaan dan opini jika terdapat informasi yang baru tentang suatu hal memberikan landasan berpikir yang efektif dalam menilai sesuatu hal sehingga membentuk sikap tertentu; 5) lembaga pendidikan dan agama serta 6) faktor emosional. Manifestasi dari sikap tidak dapat dilihat secara langsung, tetapi hanya dapat ditafsirkan terlebih dahulu dari perilaku yang tertutup (covert behavior). Setelah diberikan pendidikan kesehatan, sebagian besar sikap responden menjadi positif. Hal ini disebabkan oleh : 1) pendidikan kesehatan yang diberikan memberikan gambaran kepada remaja putri tentang manfaat mencegah keputihan sehingga mempengaruhi pemahaman dan pemikiran remaja putri dalam bersikap positif. Menurut Notoadmodjo (2003) metode pembelajaran yang digunakan mampu mempengaruhi menumbuhkan dan mengembangkan sikap, cara berpikir kritis, analitis dan logis pada remaja putri. Pada penelitian ini, peneliti menggunakan metode ceramah plus diskusi dan tugas (CPDT); 2) kesadaran remaja putri untuk menjaga kesehatan organ reproduksi didukung motivasi yang tinggi agar tidak mengalami keputihan yang disebabkan oleh penyakit. Sikap remaja putri yang masih negatif setelah pendidikan kesehatan dapat dikarenakan oleh beberapa hal yaitu 1) penyampaian informasi yang hanya sekali, menurut Azwar (2003) menyatakan dengan mengulangi informasi secara terus menerus memberikan dampak individu dapat mengenal terhadap sesuatu hal yang akan menghasilkan konsistensi dalam evaluasi yang lebih diinginkan dari informasi tersebut; 2) faktor subyek belajar, perubahan sikap memerlukan proses internal yang membutuhkan waktu dan setiap individu akan memberikan respon yang berbeda untuk berubah; 3) faktor lingkungan yaitu lingkungan fisik atau kondisi tempat belajar dan lingkungan sosial yaitu manusia dengan segala interaksinya, pada saat penelitian berlangsung kondisi ruang kelas cukup tertib namun lingkungan diluar kelas gaduh oleh siswa lain sehingga menganggu konsentrasi siswi yang sedang mendapatkan pendidikan kesehatan. Situasi ini menuntut kita sebagai seorang perawat untuk berusaha memberikan 
keyakinan (membangun kepercayaan) kepada responden agar sikap mereka dapat berubah kearah yang lebih positif. Hal ini sesuai dengan teori Imogene King (1987) yang menyatakan bahwa keperawatan berfokus pada interaksi tiga sistem: sistem personal, sistem interpersonal dan sistem sosial. Ketiganya membentuk hubungan personal antara perawat dan klien.

Menurut Khatidjah (2004) pendidikan kesehatan adalah suatu penerapan konsep pendidikan di dalam bidang kesehatan yang merupakan usaha atau kegiatan membantu individu, kelompok, atau masyarakat dalam meningkatan kemampuan untuk mencapai kesehatan yang optimal. Hal ini sesuai dengan tujuan dari pendidikan kesehatan adalah terjadinya perubahan dalam membina individu, keluarga, atau masyarakat dalam membina dan memelihara perilaku sehat dan lingkungan sehat serta berperan aktif dalam upaya mewujudkan derajat kesehatan yang optimal (Notoadmodjo, 2003). Dalam penelitian ini metode yang digunakan adalah metode ceramah plus diskusi dan tugas (CPDT). Dalam metode ceramah plus diskusi dan tugas (CPDT), tidak hanya peneliti yang menjelaskan tentang materi tetapi keterlibatan remaja putri juga diperlukan dalam proses pemberian informasi. Keaktifan dan keikutsertaan remaja putri lebih efektif dapat meningkatkan kemampuan untuk mengingat dan memahami hal baru dalam hal ini adalah tentang keputihan dan cara pencegahannya.

Pemberian informasi dimaksudkan untuk menciptakan suatu perilaku sehat sehingga tidak terjadi sakit. Hal ini ditunjukkan dengan terjadinya peningkatan pemahaman yang merupakan awal dari meningkatnya pengetahuan remaja putri tentang pencegahan keputihan.

\section{Kesimpulan}

1. Pengetahuan remaja putri di SMPN 29 Surabaya tentang pencegahan keputihan meningkat setelah diberikan pendidikan kesehatan dengan metode ceramah plus diskusi dan tugas (CPDT).

2. Sikap remaja putri di SMPN 29 Surabaya tentang pencegahan keputihan menjadi positif setelah diberikan pendidikan kesehatan dengan metode ceramah plus diskusi dan tugas (CPDT).

3. Ada pengaruh antara pendidikan kesehatan dengan metode ceramah plus diskusi dan tugas (CPDT) terhadap pengetahuan dan sikap remaja putri di SMPN 29 Surabaya tentang pencegahan keputihan.

\section{Daftar Pustaka}

Arikunto, S. (2002). Manajemen Penelitian. edisi kelima. Jakarta: Rineka Cipta, Hal : 178-198.

Arikunto, S. (2006). Prosedur Penelitian: Suatu Pendekatan Praktik. Edisi 6. Jakarta: Rineka Cipta.

Alimul, A.(2003). Riset Keperawatan dan Teknik Penulisan Ilmiah. Jakarta: Salemba Medika.

Alisa, A. (2005). Kesehatan Reproduksi. edisi keempat. Jakarta: EGC.

Angkaeni, F. (2002). Efektivitas Pendidikan Kesehatan Antara Metode Ceramah dan Diskusi Terhadap Peningkatan dan Perubahan Sikap Tentang Kesehatan Reproduksi Pada Remaja Wanita. Skripsi tidak untuk dipublikasikan. Universitas Airlangga, Unair, Surabaya.

Aninditi, W. (2001). Faktor Kejadian Kandidiasis Vaginalis Terhadap Akseptor KB. Tesis tidak dipublikasikan, Fakultas Kesehatan Masyarakat, Universitas Airlangga, Surabaya.

Azwar, A. (2003). Sikap Manusia: Teori Dan Pengukurannya. Yogyakarta: Pustaka Pelajar, Hal 4-5, 15-17, 23-24, 30-38.

Bobak, L. (2005). Keperawatan Maternitas. Edisi keempat. Jakarta: EGC. 
Clayton, C. (1996). Seri Kesehatan Wanita, Keputihan Dan Infeksi Jamur Candida. Jakarta: Arcan Pustaka.

Darmani, E. (2003). Hubungan Antara Angka Kejadian Kandidiasis Vaginalis Dengan Akseptor KB. http://www.usu__ digital_ library.ac.id. tanggal 28 april 2008. Pukul 13.32WIB.
Dumilah, S. (1982). Candida dan Kandidiasis Pada Manusia. http://www.republika.co.id. Tanggal 20 April 2008. Pukul 15.05 WIB.

Gulo, W. (2002). Metode-Metode Yang Dapat Mendukung Pengajaran. http// 